\title{
ПЕДАГОГІЧНИЙ ДИСКУРС ПРО РЕФОРМУВАННЯ ШКІЛЬНОЇ ОСВІТИ (ПОЧАТОК ХХ СТ. - 1917 Р.) У РУСЛІ РОЗБУДОВИ НОВОЇ УКРАЇНСЬКОЇ ШКОЛИ
}

Із дня проголошення незалежності України освітяни сконцентрували зусилля на розвитку національної системи загальної середньої освіти. Нині в ході розбудови Нової української школи набуває актуальності історія вітчизняних освітніх реформ і контрреформ. В усі часи реформаційні процеси були предметом педагогічного дискурсу. Інноваційні ідеї педагогів та громадських діячів більшою чи меншою мірою в певний історичний період впливали на організаційнозмістові основи реформування шкільної освіти або ж залишалися нереалізованими через суспільно-політичні причини за життя авторів до їх відродження в демократичному суспільстві. 3 огляду на це доцільним є звернення до поглядів українських педагогів початку XX ст. щодо створення нової української школи. Спробуємо провести паралелі.

У той час на українських землях, що входили до складу Російської імперії, функціонувала станова, позанаціональна, платна, централізована, різнотипна, сформована в процесі шкільних реформ ХІХст. у контексті суспільнополітичних, соціально-економічних, педагогічних, культурологічних детермінант шкільна освіта, про що ми писали у своїх (Л. Д. Березівська) публікаціях [2; 5]. Самодержавний уряд ініціював і водночас гальмував освітні реформи, поєднуючи традиції та новації. Станова система освіти не відповідала запитам суспільства й не задовольняла освітянську громадськість. Педагоги на сторінках преси, з'їздах аналізували вітчизняний i зарубіжний досвід реформування освіти. За якими напрямами мала б реформуватися шкільна освіта на початку XX ст.? Які принципи повинні лягти в основу шкільної освіти? Ці та інші питання, що актуалізуються й нині в умовах розбудови Нової української школи, обговорювали освітяни на початку XX ст.

Історіографічний огляд дає підстави стверджувати, що загалом різні аспекти розвитку загальної середньої освіти початку XX ст. 1917 р. вивчали українські вчені (Н. Б. Антонець (Копиленко), Л.Д. Березівська, Н. М. Гупан,
О. М. Друганова, .В.Зайченко, Н. М. Коляда,

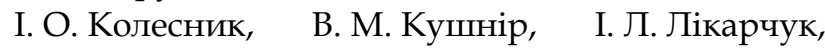
С. С. Остапчук, О. В. Перетятько, О. Б. Петренко, О. В. Попова, С. О. Роєнко, О. В. Сухомлинська, Т. О. Шаравара та ін.). У своїх працях (Л. Д. Березівська) ми розкривали організаційно-змістові основи реформування шкільної освіти на початку XX ст. - 1917 р. [2; 3; 4; 5]. Водночас меншою мірою висвітлюються ідеї вітчизняних педагогів, громадських діячів (Б. Д. Грінченко, С. О. Сфремов, О. Ф. Музиченко, С. Ф. Русова, Я. Ф. Чепіга, С. Ф. Черкасенко та ін.) стосовно зазначеного питання, хоча їхнє життя та науково-педагогічна діяльність стали предметом різноаспектних досліджень сучасних науковців (Н. Б. Антонець, Л. Д. Березівська, Н. І. Богданець-Білоскаленко, Н. П. Дічек, . В. Зайченко, С. І. Коваленко, Н. С. Побірченко, О. В. Сухомлинська та ін.). Найбільш повно біографії педагогів, громадськоосвітніх діячів, педагогічні біографічні наративи висвітлено в колективному посібнику «Українська педагогіка в персоналіях» (2003) [22]. Інформаційно-бібліографічний ресурс «Видатні педагоги України та світу» Державної науковопедагогічної бібліотеки України імені В.О.Сухомлинського НАПН України представляє життєвий шлях і науковий доробок українських педагогів та відображає ступінь їх дослідженості в науковому просторі (http://dnpb.gov.ua/ua/ інформаційно-бібліографічні-ресурси/видатніпедагоги/) [1]. Отже, використання історіографічного підходу уможливило встановлення наукової новизни обраної проблеми - педагогічний дискурс щодо реформування загальної середньої освіти початку XX ст. не був предметом цілісної історико-педагогічної розвідки. У процесі джерелознавчого пошуку було дібрано й систематизовано праці українських педагогів, громадських діячів, які опубліковані на сторінках періодичних видань досліджуваного періоду («Світло», «Українська хата», «Украинский вестник», «Украинская жизнь» та ін.), інших видань.

Мета статті - на основі дібраних джерел розкрити провідні ідеї вітчизняних педагогів про 
реформування шкільної освіти в імперську добу (початок XXст. - 1917 р.), актуалізувавши їх в умовах розбудови Нової української школи. Надалі тексти цих праць плануємо впорядкувати в хрестоматію як форму репрезентації джерел про розвиток української педагогічної думки щодо реформування загальної середньої освіти на початку XX ст.

Центральним питанням дискурсу на сторінках педагогічних видань, з'їздах, у Державній думі (у їі складі діяла Українська думська громада на правах парламентської фракції) стала розбудова украӥнської школи. Передусім критиці підлягала державна освітня політика Російської імперії. Так, відомий український педагог Я. Ф. Чепіга (Зеленкевич) стверджував, що русифікаторська система шкільної освіти на українських землях була антипедагогічною, антиприродною, бо знищувала індивідуальні риси, духовні здібності дитини. Він зауважував: «Така освіта втрачає свої основні риси - природність, привабливість і здатність будити творчість духу в дитині» [26, с. 94]. Знаний український педагог С. Ф. Черкасенко критично оцінював підходи Міністерства народної освіти до шкільного реформування, зокрема зазначав: «Міністерська реформа народної школи іде всупереч із життям, народилась вона десь поза живим життям, в бюрократичних кабінетах...» [29, с. 6]. На його думку, міністерський проєкт має стати предметом детального обговорення на освітянському з'їзді.

Членкиня Української парламентської фракції Державної думи, відома педагогиня, громадська діячка С. Ф. Русова, проаналізувавши численні заяви, клопотання українських учительських просвітницьких, студентських організацій, з'їздів селян, преси щодо розвитку української школи, дійшла висновку, що лише зміни мови викладання недостатньо, потрібно розробити такий законопроєкт, який забезпечив би Україні національну школу з рідною мовою. «Яким би страшним не було пригнічення централізму, український народ не втратив своєї національної самосвідомості і тисячі голосів вимагають тепер своїх національних прав i передусім задоволення свого фізіологічного голоду землі, і духовної спраги - рідної школи», - писала Софія Федорівна [20, с. 119, с. 121].

Предметом педагогічного дискурсу стали принциили нової украӥнської школи. Цікавим є факт вживання на початку XX ст. терміна «нова школа». С. Ф. Русова вважала, що поняття «нова школа» для будь-якої держави - це за своєю суттю «неминуче національна школа» [17]. Вона коротко описала нову школу, розроблену німецьким педагогом Г. Кершенштейнером - «німецьку практично-трудову школу, де самодіяльність дітей не перешкоджає розвитку почуття своєї обов'язкової громадянської праці». Висвітлила досвід видатного німецького педагога В. Отто щодо створення моделі школи-родини (пріоритетність дитини, взаємне навчання, праця, активні методи навчання: екскурсії, спектаклі, спостереження, дослід). Софія Федорівна на основі аналізу поглядів європейських (Г. Кершенштейнер, С. Редді, О. Декролі та ін.) і російських учених (О. П. Нечаєв, І. К. Кайданов, О. О. Фортунатов та ін.) дійшла висновку, що нова українська школа має «вбирати в себе усі поступові погляди закордонних реформаторів, але одночасно будувати свою нову форму на національнім грунті, одповідаючи на перші потреби краю, на національні вимоги люду» [17, с. 36]. Згідно 3 думкою видатної педагогині, школа повинна бути громадською, демократичною, позастановою, здійснювати національне, громадянське, трудове, естетичне й фрізине виховання учнів, без покарань інагород.

Учителі Київської губернії у схваленій резолюції «Про народну освіту» (1906) освітянського з'їзду обгрунтували принципи шкільної освіти, яка має бути загальною та безплатною, єдиною, державною, рідномовною, світською тощо [18]. Я. Ф. Чепіга виокремлював такі головні характеристики школи: народна, національна, природна, вільна, реалістична [23, с. 3-7], кожну з яких він ретельно описав. На думку С. Ф. Русової, школа повинна бути гуманною, активно-творчою, національною [19, с. 191].

Як свідчить педагогічний дискурс початку XX ст., школа має бути передусім національною. Який зміст вкладали педагоги в це поняття? «...народна правдива школа може бути створена тільки в дусі нації, іï мови, іiі історії, звичаїв, іiї переказів, іiї культури, іï духовної творчості, і тільки така школа не відірве дитину від іï дійсного грунту, тільки тоді не буде дитина пересаджена на чужий іï природі грунт», - пояснював Я. Ф. Чепіга $[23$, с. 4]. Відомий громадський діяч і науковець С. О. Єфремов умотивовував ідею про розроблення національної системи освіти в складі взаємозв'язаних між собою всіх ланок освіти (початкова, середня, вища) [8, с. 21].

У руслі створення української школи педагогічна громадськість вважала стратегічним завданням реформування загальної середньої освіти запровадження украӥнської мови в освітній процес. У своїх працях педагоги розкривають багатовікову історію цього питання, наводять приклади обстоювання освітянами, громадськими діячами української мови як навчального предмета та мови навчання. «...чимало педагогів, земств, міських дум та інших установ висловилися в тому ж дусі, як і Ушинський, тобто негативно щодо існуючої для українців чужемовної школи та за заміну іï школою 3 українською мовою викладання. Необхідність цього випливає насамперед 
iз факту незрозумілості школярем-українцем російської мови, якою здійснюється в нинішній час навчання», - доводив відомий український педагог Б. Д. Грінченко [6, с. 19]. У своїх міркуваннях про рідномовне навчання він звертався до ідей знаних вітчизняних (М. І. Костомаров, К. Д. Ушинський) і зарубіжних (німецьких А. Дістервега, В. Гумбольдта, А. Ріхтера та ін.; французького - М. Бреаля) учених, педагогів. Думки Бориса Дмитровича стосовно запровадження української мови в освітній процес актуалізуються й нині в умовах хвилеподібного загострення дискурсу щодо мовного питання в незалежній Україні: «...запровадження ії (української мови - Л. Б.) в шкільне викладання зумовлено основними вимогами педагогіки й дидактики, і тільки після виконання цієї вимоги і буде можливим серйозно говорити про освіту українського народу. I оскільки українська мова $є$ мовою, яка має літературу, то запроваджувати іï потрібно як мову викладання, якою вчать і яку вивчають» $[6$, с. 70].

Розмірковуючи про необхідність навчання рідною мовою, відомий педагог, учений-історик В. К. Прокопович, спираючись на ідеї К. Д. Ушинського, Б. Д. Грінченка, Яна Коменського, наголошував: «школа, намагаючись позбавити учня його рідної мови, вносячи плутанину в його поняття, замінюючи материнську мову жаргоном, знижує його розумовий рівень, вбиває в ньому бажання до читання книжок, розуміння яких для нього є надзвичайно важким» [16, с. 27].

Актуальною й тепер є думка українського громадського діяча та науковця О. Г. Лотоцького про значення рідномовного навчання для розвитку «духовних і матеріальних» сил українського населення. Він розглядав українську мову передусім «могутньою зброєю шкільного навчання» і водночас однією 3 істотних умов «засвоєння знань і взагалі культурного й економічного прогресу народної маси» [11, с. 74]. Ідею навчання рідною мовою у всіх ланках загальної середньої освіти розвивав С. О. Сфремов. Він писав: «Бажана ліквідація національних обмежень, але для всіх однакова. Допускаючи, наприклад, польську мову в школах південно-західних губерній, не допускати малоросійської немає ніяких підстав» $[9$, с. 279].

У цьому руслі глибокими й проникливими $є$ думки Я. Ф. Чепіги: «...примушувати український народ балакати російською мовою, заводити школи всюди на Україні цією мовою, добувати знання чужою нерідною мовою це однаково, що присудити мільйони люду на духовну смерть. Відняти мову в народу це однаково, що відняти у нього творчий геній, активну силу розумової діяльності, бо вся найвища духовна діяльність людини, психічний склад іiі є наслідком іiі націо- нальності, здобутком мови» [24, с. 338]. Яків Феофанович, спираючись на ідеї таких відомих педагогів i філософів, як Дж. Лок, М. Монтень, І. Г. Песталощці, Ж.-Ж. Руссо, Ф. В. Фребель, Л. М. Толстой, К. Д. Ушинський, висловив міркування про відтворення права дитини навчатися материнською мовою в новій школі [27].

Питання про рідномовне навчання в цей час стало одним із пріоритетних на освітянських з'їздах. У прийнятій постанові «Резолюція про викладання рідною мовою» на Першому всеросійському з'їзді діячів товариств народних університетів (1908 р., Санкт-Петербург), де була присутня й українська делегація, було задекларовано: «з'їд визнає за кожною національністю невід'ємне право здобувати освіту ії рідною мовою» $[21$, с. 29].

Серед ключових у розглядуваному педагогічному дискурсі постає принцип природовiдnовiдності. Осмислюючи його, Я.Ф. Чепіга зазначав, що «оскільки дух нації полягає в природі ї̈ окремих індивідуумів, що становлять націю, то школа повинна створитись на законах природи людини» [23, с. 4-5]. Він доводив, що роль школи має полягати в підтримуванні та розвиткові природних нахилів учнів, керуванні дитиною єдиним природним засобом - волею, що ... забезпечить досягнення загальнолюдської ідеї виховання - дати громадянству найліпшу непопсовану людину» [23, с. 5-6]. Цей принцип тісно пов'язаний із принципом дитиноцентризму. С. Ф. Черкасенко пов'язував «реорганізацію навчальної справи на нових засадах» 3 українізацією школи, під якою він розумів не лише впровадження в заклад освіти української мови, а й розвиток усіх природних здібностей дитини [28, с. 46].

Педагоги обмірковували й інші принципи, назви яких не завжди відповідають нинішнім, проте змістове наповнення свідчить про їхню спорідненість. Наприклад, Я.Ф. Чепіга вважав, що школа має бути ще й реалістичною, тобто давати знання, необхідні для життя. Як ми розуміємо, йдеться про приниип зв'язку школи 3 життям. Педагог називав книжне навчання «найлютішим ворогом освіти». При цьому висловлював рекомендації: «Справжній школі не годиться ганятись за книжними знаннями - вона готує дітей до життя, де потрібні тільки ті, що принатурились ще в школі до нього, ще в школі привчались володіти знаннями власного досвіду» [23, с. 6]. Цей принцип обстоював i С. О. Єфремов: «Зміст шкільної науки треба пристосувати до життя, до його вимагань, тобто в першу чергу подавати учням відомості про ті обставини, з якими матимуть вони діло в самому житті, - це перше. Друге, відомості ці повинно подавати учням їхньою мовою, зрозумілою їм до 
найдрібніших відтінків. У цих двох основних нормах лежать у зародку всі вимагання справжньої, на досвіді й розумі заснованої, педагогіки» [8, с. 21]. Відомий вітчизняний педагог Т. Г. Лубенець у цьому ж руслі писав: «Школа майбутнього має дати державі чесну людину, що живе за заповітами Христа; господаря, який любить свою справу...; працівника, який любить своє поле, цікавиться його долею, бажає знайти і вміє шукати для цього знання» [12, с. 203].

Як і С.Ф. Русова та Я.Ф. Чепіга, знаний український педагог О. Ф. Музиченко обгрунтовував принцип демократизації загальної середньої освіти. Вивчаючи тенденції розвитку європейської системи освіти, часто спираючись на ідеї німецьких філософів і педагогів Ф. Паульсена, Г. Літца, він доводив, що «демократизація школи ні за що не може означати популяризацію знань і можливе полегшення і зниження вимог», в ії основу має бути покладена педагогіка, яка «ставить вимогу підготувати сильну і прекрасну людину, високо і гармонійно розвинути розум, тіло і волю, моральні сили дитини» [14, с. 20-21]. У руслі здійснення реформи шкільної освіти О. Ф. Музиченко розмірковував про активні методи навчання, наочність навчання, виховуюче навчання. При цьому він звертався до ідей німецького педагога-реформатора Г. Гаудігома, американського філософа й педагога В. Джеймса та ін. Олександр Федорович запитував: «Ми поставлені перед новою важливою проблемою: чи може бути активний, хороший метод за поганих навчальних програм?» I сам відповів: «Без навчального плану й вдумливо розроблених програм найкращі методи будуть лише танцями і співом при жертвоприношенні дикунів» [13].

Педагогічний дискурс початку XX ст. щодо реформування загальної середньої освіти характеризується цілеспрямованістю й поліаспектністю. Особливо жваво обговорювали педагоги структуру та зміст освіти. На основі вітчизняного й зарубіжного досвіду освітяни розробляли проєкти нової української школи.

Для реалізації принципів демократизації освіти, іiі доступності всім верствам суспільства під керівництвом відомого педагога, директора народних училищ Київської губернії Т. Г. Лубенця був створений Проєкт запровадження загального обов'язкового навчання $b$ м. Києвi. У його основу лягли такі положення: «всім дітям обох статей надається можливість після досягнення шкільного віку пройти повний курс навчання в правильно організованій школі»; «нормальна тривалість курсу навчання в початковій однокласній школі чотирирічний період»; до дітей шкільного віку належать чотири вікові групи - 8, 9, 10, 11 років; нормальна кількість дітей на одного вчителя 50 учнів; до шкільної мережі належать усі міські парафіяльні, міністерські, земські, церковнопа- рафіяльні школи [10, с. 1-9].

Критикуючи русифікаторську державну політику щодо неросійських народів, один із дописувачів часопису «Украинский весник» Н. Дмитрієв доводив, що початкова та середня школа має бути національною українською. Він обгрунтував зміни до змісту освіти: «поставити викладання географії серйозніше і ширше» у напрямі «вивчення рідного учням краю України», у старших класах доповнити його курсом етнографіï; запровадити на основі вивчення всього курсу історії Росії у старших класах вивчення історії рідного краю України; увести до програми літератури оригінали народної української творчості, твори найкращих українських письменників; запровадити в школах на українських землях вивчення української рідної мови; завершити вивчення природничих предметів курсом про природу на території України [7, с. 896].

Учителі Київської губернії в резолюції освітянського з'їзду народних учителів «Про українську школу» (1906) запропонували вироблену в процесі дискурсу модель української школи: термін навчання в народній школі збільшити до шести років, викладовою мовою вважати рідну мову, державну - вивчати в старших класах як навчальний предмет; в учительських семінаріях та інститутах усі предмети викладати українською мовою, а для вчителів, які вже працюють у школах, читати курси української мови, історії, літератури; у середніх і вищих закладах освіти поступово ввести українську мову, літературу, історію, географію як навчальні предмети [18, с. 967].

С. Ф. Русова розробила Проєкт початкової школи, яка має бути народною, 3 навчанням українською мовою. За проєктом зміст освіти, що відображається в підручниках, читанках, повинен будуватися на історичних і географічних матеріалах рідного краю [21, с. 54]. У трирічній початковій школі пропонувалося вивчати такі предмети: 1-й клас - граматка і книжка-читанка, Закон Божий, арифметика та письмо українською мовою; 2-й клас - пояснювальне читання, Закон Божий, арифметика, українська мова, російська мова; 3-й клас - історія, географія, природознавство, українська мова та література. Зазначимо, що Софія Федорівна запропонувала й інший варіант 4-5-річної початкової школи для підготовки учнів до гімназій, торговельних шкіл, інших типів закладів освіти. Відповідно до нього школярі мали вивчати такі предмети: Закон Божий, рідна мова, арифметика, природознавство, географія, історія, ручна праця, малювання, ліпка, різьба по дереву, співи, фізичне виховання. Головною метою нової української школи, на думку педагогині, мало стати виявлення самостійних творчих сил дитини, а завданням - ро- 
звиток мислення й мови учня [19, с. 180-191]. Вона писала: «На Вкраїні рідна мова - є українська; нею й мусить проводитися вся наука» [19, с. 183].

На прохання редакції українського журналу «Світло» Я. Ф. Чепіга розробив Проєкт украӥнсъкої школи (1913). У розділі «Грунтовні постулати проєкту» він висвітлив засади побудови національної школи: «зберегти людську природу i удосконалити їі, принатурюючи до соціальних і економічних умов життя певного народу, згідно 3 вимогами людської моралі»; «школі природно бути національною»; навчання в початковій, середній і вищій школі здійснювати рідною мовою; «природно дитину залишити в стосунках із реальним світом», «побільше стосунків із природою»; «признати волю виховання й освіти в дитині» [25, с. 31-41]. У підрозділі «Перш за все свобода розвитку національних прикмет» Я. Ф. Чепіга обгрунтував необхідність рідномовного навчання: «У мові кожної людини відбивається душа іiі народна, і розвиток іiі міцно з'єднаний із розвитком народної душі» [25, с. 33]. Педагог вважав, що рідною мовою має здійснюватися навчання в початковій, середній та вищій школі. За проєктом початкова школа мала бути двоступеневою 3 шестирічним терміном навчання, яке повинно розпочинатися з шести років (перший ступінь два роки, другий ступінь - чотири роки). Влучно звучить назва одного з підрозділів «Природа дитини є основа освіти», де педагог порушує проблему індивідуального підходу в освіті: «Нехай правдивій освіті служать прикладом рослини, котрі іноді дають смачний і гарний плід, коли ростуть і розвиваються в нормальних умовах, коли догляд і піклування про них з'єднано 3 їх індивідуальністю» [25, с. 37]. До речі, розробляючи проєкт, Я. Ф. Чепіга поставив за мету «зберегти дитину щасливою, радісною й діяльною весь час шкільної освіти» [25, с. 41].

Спираючись на ідеї Б. Д. Грінченка, С. О. Єфремов висловлював своє бачення змістового наповнення української школи: «Як відомо, українські домагання в сфері середньої й вищої освіти зводяться власне до того, щоб на Україні середня й вища школа знайомила учнів із минулим і сучасним життям українського народу, тобто з його історією, письменством та мовою, 3 географією рідної землі й їі економічним становищем» [8, с. 23-24].

Отже, українські педагоги та освітні діячі (Б. Д. Грінченко, С. О. Єфремов, О. Г. Лотоцький, Т. Г. Лубенець, О. Ф. Музиченко, В. К. Прокопович, С. Ф. Русова, Я. Ф. Чепіга, С. Ф. Черкасенко та ін.) на сторінках періодичних видань, з'їздах, у Державній думі та інших зібраннях розгорнули широкомасштабний дискурс щодо реформування станової позанаціональної загальної середньої освіти задля створення нової української школи. Вони заклали підвалини нинішньої Нової укра- їнської школи, зокрема визначили їі магістральні принципи: національний, демократичний, гуманістичний, природовідповідний, дитиноцентричний, виховний, науковий, світський, зв'язок школи 3 життям та ін. Проводячи порівняльні паралелі між сучасними реформаційними процесами та понад столітньої давності, виявляємо спільну тенденцію - прагнення освітян розбудовувати українську школу на найкращих ідеях вітчизняної й зарубіжної педагогіки. Сторінки їхніх праць рясніють зверненнями до напрацювань знаних європейських учених (М. Бреаль, А. Дістервег, Г. Гаудігом, В. Гумбольдт, О. Декролі, Г. Кершенштейнер, Я. А. Коменський, Г. Літц, Дж. Лок, М. Монтень, Ф. Паульсен, І. Г. Песталоцці, С. Редді, Ж.-Ж. Руссо, Ф. Фребель та ін.).

Думки українських педагогів розвинулися в нормативних та законодавчих актах, в освітньому процесі незалежної України. Так, у стратегічному документі «Нова українська школа. Концептуальні засади реформування середньої школи» (2016) серед 10 ключових компетентностей Нової української школи тлумачиться першою - «спілкування державною (і рідною у разі відмінності) мовами» [15, с. 10]. Серед виховних цінностей не втрачають актуальності такі, як «повага до рідної мови і культури» [15, с. 19]. Сучасна нова школа, як і на початку XX ст., ставить за мету «плекати українську ідентичність» [15, c. 19]. Одним із компонентів формули теперішньої Нової української школи є орієнтація на учня, реалізація принципу дитиноцентризму $[15$, с. 17], на чому наголошували й провідні вітчизняні педагоги в попередньому столітті. I це є споріднені тенденції тогочасного та нинішнього поступу української педагогічної думки щодо реформування загальної середньої освіти. Сьогодні набувають актуальності погляди відомих педагогів початку XX ст. стосовно розбудови нової української школи. Зокрема, вартує осмислення в сучасному педагогічному дискурсі звернення Я.Ф. Чепіги понад сто років назад до освітянської громади: «...нашою школою ми повинні зберегти й охоронити духовні сили нації в дитині непопсованими, а перш за все іiі рідну мову» $[25$, с. 35$]$.

Насамкінець зазначимо, що хоча ідеї вітчизняних освітніх і громадських діячів через суспільно-політичні причини не були реалізовані за їхнього життя, вони послужили підгрунтям для розбудови нової української школи в добу Української революції (1917-1921), зацементували процес українізації освіти 20-х років XX ст. та, незважаючи на нівелювання в радянську добу, стали основою іï відродження наприкінці 80-х років XX ст., міцно вкарбувалися в освітнє законодавство незалежної України, нагадуючи про непоправні уроки історичної пам'яті. Про це йтиметься в подальших публікаціях. 


\section{СПИСОК ВИКОРИСТАНИХ ДЖРЕЛ}

1. Березівська Л. Д. Електронний інформаційнобібліографічний ресурс «Видатні педагоги України та світу» як основа професійної підготовки педагогів. Освіта для миру = Edukacja dla pokoju: у 2 т. / НАПН України [та ін.]. Київ, 2019. Т. 2. С. 222-228.

2. Березівська Л. Д. Реформування загальної середньої освіти в Україні у XX столітті крізь призму джерелознавства: наук.-допом. бібліогр. покажч. / НАПН України, Від-ня заг. педагогіки та філософії освіти, ДНПБ України ім. В. О. Сухомлинського. Вінниця: Твори, 2019. $251 \mathrm{c}$.

3. Березівська Л. Д. Реформування шкільної освіти в Україні у XX ст.: історіографія питання. Історико-педагогічний альманах. 2009. Вип. 1. C. 15-28.

4. Березівська Л.Д. Розвиток ідей про реформування шкільної освіти в Україні (1905-1914). 3б. наук. пр. Херсон. держ. ун-ту. Педагогічні науки. Херсон, 2005. Вип. 40. С. 53-59.

5. Березівська Л. Д. Спроби реформування шкільної освіти в імперську добу (1899-1917): історіографія та джерела дослідження. Історико-педагогічний альманах. 2017. Вип. 1. C. 32-30.

6. Грінченко Б. Д. На беспросветном пути: об украинской школе. Изд. 2-е, испр. Київ: Вік, 1905. 101 c.

7. Дмитрієв Н. Нужды средней школы. Укр. вестник. 1906. № 12. С. 890-897.

8. Єфремов С. «Вони не просять»... Світло. 1911. № 4. C. 21-27.

9. Ефремов С. Указ 1 мая. Киељ. старина. 1905. T. LXXXIX. C. 271-304.

10. Краткий обзор постепенного развития школьного дела в г. Киеве 1870-1908 гг. Известия Киевской городской думы. Киев, 1909. № 4. С. 1-57.

11. Лотоцкий А. Школа без языка. Вестн. воспитания. 1906. № 7. С. 64-74.

12. Лубенец Т. Какие требования предъявляет народ к школе. Журн. М-ва нар. просвещения. 1912. № 4. C. 195-204.

13. Музиченко О. Виховуючий вплив навчання / [вступ. ст., підгот. тексту й прим. до публ., пер. 3 рос. Ольги Сухомлинської]. Історикопедагогічнии альманах. 2006. Вип. 1. С. 82-93.

14. Музыченко А. Ф. На пути к демократизации школы (из отчета профессорского стипендианта). Русская шк. 1907. № 5. С. 1-22.

15. Нова українська школа: концептуальні засади реформування середньої школи: ухвалено рішенням колегії МОН України від 27.10.2016. Міністерство освіти і науки України: [офіц. портал]. Київ, 2016. 34 c. URL: https://mon.gov. ua/storage/app/media/zagalna $\% 20$ serednya/n ova-ukrainska-shkola-compressed.pdf

(дата звернення: 24.07.2020).

16. Прокопович В. Школа и родной язык в Украине. Украинская жизнъ. 1914. № 4. С. 27-33.

17. Русова С. Ідейні підвалини школи. Світло. 1913. № 5. C. 33-38.

18. Русова С. Курсы народных учителей в Киеве. Укр. Вестн. 1906. № 14. С. 964-968.

19. Русова С. Нова школа. Педагогічна конщепиія С. Ф. Русової: навч. посіб. для студентів пед. спец. вузів / І. В. Зайченко; [передм. М. Д. Ярмаченка]. 2-ге вид., допов. і перероб. Чернігів, 2000. C. 180-191.

20. Русова С. Современные школьные нужды в Украине. Укр. Вестн. 1906. № 2. С. 115-122.

21. Труды Первого Всероссийского съезда деятелей обществ народных университетов и других просветительных учреждений частой инициативы. Санкт-Петербург: Север, 1908. $526 \mathrm{c.}$

22. Українська педагогіка в персоналіях: у 2 кн.: навч. посіб. для студентів вищ. навч. закл. / [О. В. Сухомлинська, Н. Б. Антонець, Л. Д. Березівська, Л. С. Бондар, Н. Я. Бугаєнко, Н. П. Дічек, Т. К. Завгородня, Т. О. Ляпіна, І. П. Маноха, Л. В. Пироженко, Н. С. Побірченко, Т. О. Самоплавська, Б. М. Ступарик, В. В. Тригубенко, О. А. Удод, Т. В. Філімонова]; за ред. О. В. Сухомлинської. Київ: Либідь, 2005. Кн. 1: X-XIX століття. 621, [3] с.; Кн. 2: ХХ століття. 549, [3] c.

23. Чепіга Я. Ф. Ірунтовні принципи нормальної школи. Світло. 1911. № 1. С. 3-7.

24. Чепіга Я. До національної школи. Українська xama. 1909. № 6. С. 337-339.

25. Чепіга Я. Ф. Проект української школи. Грунтовні постулати проекта. Світло. 1913. № 2. C. 31-41.

26. Чепига Я. Просвещенное невежество. Укр. жизнъ. 1912. № 9. С. 92-94.

27. Чепига Я. Ф. Украинский учитель и материнский язык в начальной школе. Укр. жизнъ. 1913. № 9. С. 9-14.

28. Черкасенко С. Голос украинских учителей. Укр. жизнь. 1912. № 6. С. 38-46.

29. Черкасенко С. Поза життям. Свimло. 1913. № 3. C. 3- 6.

30. Черкасенко С. Те, без чого не обійдешся. Світло. 1913. № 2. С. 3-5.

\section{REFERENCES}

1. Berezivska, L. D. (2019). Elektronnyi informatsiinobibliohrafichnyi resurs "Vydatni pedahohy Ukrainy ta svitu" yak osnova profesiinoi pidhotovky pedahohiv. Osvita dlia myru = Edukacja dla pokoju. Kyiv, Vol. 2, 222-228 [in Ukrainian].

2. Berezivska, L. D. (2019). Reformuvannia zahalnoi 
serednioi osvity v Ukraini u XX stolitti kriz pryzmu dzhereloznavstva: naukovo-dopomizhnyi bibliohrafichnyi pokazhchyk. Vinnytsia: Tvory [in Ukrainian].

3. Berezivska, L. D. (2009). Reformuvannia shkilnoi osvity v Ukraini u XX st.: istoriohrafiia pytannia. Istoryko-pedahohichnyi almanakh, Issue 1, 15-28 [in Ukrainian].

4. Berezivska, L. D. (2005). Rozvytok idei pro reformuvannia shkilnoi osvity v Ukraini (19051914). Zbirnyk naukovykh prats Khersonskoho derzhavnoho universytetu. Pedahohichni nauky Collection of research papers "Pedagogical sciences», Issue 40, 53-59 [in Ukrainian].

5. Berezivska, L. D. (2017). Sproby reformuvannia shkilnoi osvity v impersku dobu (1899-1917): istoriohrafiia ta dzherela doslidzhennia. Istorykopedahohichnyi almanakh - Educational History Review, issue 1, 32-30 [in Ukrainian].

6. Hrinchenko, B. D. (2005). Na besprosvetnom puti: ob ukrainskoy shkole (2nd ed.). Kyiv: Vik [in Russian].

7. Dmytriev N. (1906). Nuzhdy sredney shkoly. Ukr. Vestnik, 12, 890-897 [in Russian].

8. Yefremov, S. (1911). «Vony ne prosiat»... Svitlo, 4, 21-27 [in Ukrainian].

9. Efremov, S. (1905). Ukaz 1 maya. Kiev. starina. LXXXIX. 271-304 [in Russian].

10. Kratkiy obzor postepennogo razvitiya shkol'nogo dela v g. Kieve 1870-1908 gg. (1909). Izvestiya Kievskoy gorodskoy dumy. Kiev, 4, 1-57 [in Russian].

11. Lototskiy, A. (1906). Shkola bez yazyka. Vestnik vospitaniya, 7, 64-74 [in Russian].

12. Lubenets, T. (1912). Kakie trebovaniya predieyavlyaet narod k shkole. Zhurnal Ministerstva narodnogo prosveshcheniya, 4, 195-204 [in Russian].

13. Muzychenko, A. F. (1907). Na puti k demokratizatsii shkoly (iz otcheta professorskogo stipendianta). Russkaya shkola, 5, 1-22 [in Russian].

14. Muzychenko, O. \& Sukhomlynska, O. (Eds.) (2006). Vykhovuiuchyi vplyv navchannia. Istoryko-pedahohichnyi almanakh - Educational History Review, issue 1, 82-93. URL: http://ipa.udpu.edu. ua/article/view/15071/12881/ [in Ukrainian].

15. Nova ukrainska shkola: kontseptualni zasady reformuvannia serednioi shkoly: ukhvaleno rishenniam kolehii MON Ukrainy vid 27.10.2016. URL: https://mon.gov.ua/storage/app/media/ zagalna\%20serednya/nova-ukrainska-shkolacompressed.pdf [in Ukrainian].

16. Prokopovich, V. (1914). Shkola i rodnoi yazyk v Ukraine. Ukrainskaya zhizn, 4, 27-33 [in Russian].

17. Rusova, S. (1913). Ideini pidvalyny shkoly. Svitlo, 5, 33-38 [in Ukrainian].

18. Rusova, S. (1906). Kursy narodnykh uchiteley v Kieve. Ukrainskii vestnik, 14, 964-968 [in Russian].

19. Rusova, S. (2000). Nova shkola. I. V. Zaichenko \& Yarmachenko, M. D. (Ed.) Pedahohichna kontseptsiia S. F. Rusovoi. Chernihiv, 180-191 [in Ukrainian].

20. Rusova, S. (1906). Sovremennye shkolnye nuzhdy v Ukraine. Ukrainskii vestnik, 2, 115-122 [in Russian].

21. Trudy Pervogo Vserossiiskogo syezda deyateley obshchestv narodnykh universitetov i drugikh prosvetitelnykh uchrezhdeniy chastoy initsiativy (1908). Sankt-Peterburg: Sever [in Russian].

22. Sukhomlynska, O. V., Antonets, N. B., Berezivska, L. D., Bondar, L. S., Buhaienko, N. Ya., Dichek, N. P. ... Filimonova T. V. (2005). Ukrainska pedahohika $\mathrm{v}$ personaliiakh. (Vols. 1-2); Vol. 1: X-XIX stolittia; Vol. 2: XX stolittia. Kyiv: Lybid [in Ukrainian].

23. Chepiha, Ya.F. (1911). Hruntovni pryntsypy normalnoi shkoly. Svitlo, 1, 3-7 [in Ukrainian].

24. Chepiha, Ya. (1909). Do natsionalnoi shkoly. Ukrainska khata, 6, 337-339 [in Ukrainian].

25. Chepiha, Ya. F. (1913). Proekt ukrainskoi shkoly. Hruntovni postulaty proekta. Svitlo, 2, 31-41 [in Ukrainian].

26. Chepiga, Ya. (1912). Prosveshchennoye nevezhestvo. Ukrainskaya zhizn, 9, 92-94 [in Russian].

27. Chepiga, Ya. F. (1913). Ukrainskiy uchitel i materinskiy yazyk v nachalnoy shkole. Ukrainskaya zhizn, 9, 9-14 [in Russian].

28. Cherkasenko, S. (1912). Golos ukrainskikh uchiteley. Ukrainskaya zhizn, 6, 38-46 [in Russian].

29. Cherkasenko S. (1913). Poza zhyttiam. Svitlo, 3, 3-6 [in Ukrainian].

30. Cherkasenko S. (1913). Te, bez choho ne obiideshsia. Svitlo, 2, 3-5 [in Ukrainian]. 